glad to give any advice on the setting up of such research.

\section{Recommendation 24}

The College should promote study of the compulsory admission process in black communities in an attempt to tease out the complex factors which operate and as a basis for improving practice and restoring confidence.

The Committee notes that the Mental Health Act Commission is also moving towards a particular interest in this field and urges priority consideration by the Commission of a very sensitive and important area. It recommends that the College open discussion with the Commission about a joint approach to the problem.

The College is aware of the findings that AfroCaribbeans are over-represented among compulsory admissions and in forensic units. Our comments on Recommendation 23 are relevant to this issue. There may well be different obstacles and pathways to psychiatric care between ethnic minority groups and the indigenous population and these may start at the level of primary care and community structures.

An important practical step is to promote communication and understanding between those providing psychiatric services and multi-racial community groups in the locality. Regular participation of psychiatrists with such groups and with individual representatives of ethnic minorities have greatly benefitted psychiatric services. It is a reasonable hope that such approaches, by promoting understanding between the services and the local populations, will reduce distrust, improve the availability of psychiatric services and reduce the need for compulsory admission.
The College is aware of the Mental Health Act Commission's concern on this matter and will be discussing this with the Commission.

\section{Recommendation 25}

In the context of their daily work, members of the College should take a lead by example and by education in countering any tendency to racial discrimination against patients or against staff by staff of all categories, including doctors.

The College would strongly support this recommendation.

\section{Recommendation 26}

The Court of Electors should consider what steps the College might take to discipline members, especially those who were representing the College in some capacity, who had manifested racism or racial discrimination in a professional context.

The Court of Electors already has powers to take action, varying from informal or formal warnings, to reprimands, or actual deprivation of membership of the College. Such actions have been based on very clear evidence obtained either by invigilators, examination organisers, College Officers or by the GMC itself, or by other bodies who use legal or quasi-legal procedures.

If the College received information, on the basis of evidence which had already been evaluated, from Health Authorities, or other bodies, that a College member had been behaving improperly, with respect to racial or sexual discrimination, in a professional context, the Court of Electors would consider what action to take.

May 1990

NB Appendices 1, 2, 3 and 4 are available from the College.

\title{
Honour for President
}

Dr J. L. T. Birley was awarded the CBE in The Queen's Birthday Honours List. 